Avoimesti luettavissa osoitteessa http://journal.fi/ainedidaktiikka

ainedidaktiikka

\title{
Argumentointimallit fysiikan tiedon kuvaamisessa
}

\author{
Maija Nousiainen $^{1}$, Mikko Kesonen ${ }^{1,2}$ ja Karoliina Vuola ${ }^{1}$ \\ ${ }^{1}$ Matemaattis-luonnontieteellinen tiedekunta, Helsingin yliopisto \\ ${ }^{2}$ Luonnontieteiden ja metsätieteiden tiedekunta, Itä-Suomen yliopisto
}

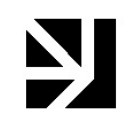

Argumentointi on tunnistettu tärkeäksi koulutuksen tavoitteeksi, minkä vuoksi sitä on painotettu luonnontieteiden opetuksessa. Painotus on avannut lupaavia mahdollisuuksia, mutta myös ongelmia, joiden ymmärtämiseksi tarkastelemme neljää argumentoinnin mallia. Tavoitteena on ymmärtää, millaisella mallilla voitaisiin kattavasti kuvata fysiikan tiedon argumentointia opettajakoulutuksen kontekstissa. Toulmin kuvaa argumentin rakennetta ottamatta kantaa sisältötiedon oikeellisuuteen. Böttcher ja Meisert kuvaavat argumentointia selitysmallien kehittymisen näkökulmasta. Sampson tarkastelee argumentointia koulukokeellisuuden näkökulmasta. Sandoval ja Millwood käsittelevät argumentin käsitteellistä ja episteemistä laatua. Argumentointimallit ovat ansiokkaita, mutta riittämättömiä fysiikan tiedon luonteen kuvaamiseksi. Niistä puuttuu muиn muassa fysiikan tiedonmuodostuksen kannalta keskeinen teorialähtöisen päätelmän näkökulma. Fysiikan tiedon argumentointiin tarvitaankin fysiikan tiedon luonteesta kumpuava malli.

Argumentointi, argumentointimallit, fysiikka

Lähetetty: 8.1.2021

Hyväksytty: 24.3.2021

Vastuukirjoittaja:maija.nousiainen@helsinki.fi

DOI: $10.23988 /$ ad.100097 


\section{Johdanto}

Nyky-yhteiskunta vaatii yksilöltä entistä monipuolisempia tiedonprosessointitaitoja ja kykyä saadun tiedon kriittiseen tarkasteluun jatkuvasti kasvavan informaation määrän vuoksi. Tiedon onnistunut käyttö edellyttää enenevissä määrin erilaisten vaihtoehtojen kriittistä tarkastelua sekä täsmällistä että vakuuttavaa perustelua valitun vaihtoehdon asianmukaisuuden vakuudeksi. Tällainen ihmismielen tai -ryhmän prosessi voidaan nähdä argumentointina, jonka aikana muodostetaan tai arvioidaan perusteltuja väittämiä olemassa olevaan evidenssiin tukeutuen. Prosessin lopputulemana muodostuu argumentti ${ }^{1}$, eli kantaaottava, ja evidenssiin nojautuva perusteltu väite (ks. esim. Shebab \& Nussbaum, 2014).

Monessa yhteydessä argumentointitaidot on tunnistettu tärkeäksi opetustavoitteeksi kaikilla koulutuksen asteilla (Fischer ym., 2014; Rapanta, Garcia-Mila \& Gilabert, 2013; Tiruneh, de Cock, Weldeslassie, Elen \& Janssen, 2016). Lisäksi tieteellinen lukutaito ja siihen liittyen tieteellisen argumentoinnin ymmärtäminen on nimetty keskeisiksi 2000luvun taidoiksi (Turiman, Omar, Daud \& Osman, 2012). Kouluilla ja opettajilla onkin siten keskeinen rooli kriittisen ajattelun ja perustelutaitojen opettamisessa ja niiden harjaannuttamisessa, jotta koulutuksella voidaan ohjata opiskelijoita kestävien valintojen tekemisessä.

Argumentointitaitojen kehittymistä voidaan tukea korostamalla näiden merkitystä kaikilla koulutuksen asteilla (von Aufschnaiter, Erduran, Osborne, \& Simon, 2007; Fischer ym. 2014; Rapanta ym., 2013). Luonnontieteiden opetus- ja oppimistavoitteita onkin viime vuosina laajennettu sisältötiedon hallinnasta kohti laaja-alaisempia teemoja, kuten luonnontieteellistä lukutaitoa (Kokkonen \& Laherto, 2018) ja tähän koulutushaasteeseen on vastattu myös muun muassa argumentointia painottamalla (Cavagetto, 2015). Argumentoinnin opetus on nähty potentiaalisena menetelmänä sisältötiedon opettamiseksi ja itsessään tärkeäksi oppimistavoitteeksi (ks. esim. von Aufschnaiter ym., 2007; Erduran, Ozdem \& Park, 2015; Erduran, Simon \& Osborne, 2004; JiminézAleixandre \& Erduran, 2008; Rapanta ym., 2013).

Kriittisen ajattelun ja argumentointitaitojen opettamisen edellytys on, että oppiaines esitetään loogisessa järjestyksessä ja siihen sisältyvät perusteluketjut ovat eheitä. Koherentin ja hyvin järjestäytyneen sisältötiedon lisäksi argumentointitaito onkin tärkeä tavoite luonnontieteiden ja erityisesti fysiikan aineenopettajien koulutuksessa. Voidaan nimittäin nähdä, että argumentointitaitojen tukeminen auttaa opiskelijaa myös sisältötiedon hallinnassa (Mercer, 2009; ks. myös Vuola \& Nousiainen, 2020; Nousiainen 2017), mutta on voitu osoittaa, että pitkällekin edistyneillä opettajaopiskelijoilla on hankaluuksia pätevässä tiedon argumentoinnissa (ks. Mäntylä \& Nousiainen, 2014; Nousiainen, 2017; Nousiainen, 2013),

1 Argumentti rinnastetaan usein luonnontieteiden opetuksen tutkimuskirjallisuudessa selitykseen (Osborne ja Patterson, 2011), joka voidaan nähdä argumenttia vähemmän spekulatiivisempana tietokokonaisuutena. Argumentti puolestaan sisältää aina perustelun (Shebab \& Nussbaum, 2014). 
mikä väistämättä vaikuttaa tulevaan kouluopetukseen. Niinpä opettajankoulutuksessa tarvitaan tukea ja käytännön työkaluja opiskelijoiden argumentointitaitojen kohentamiseksi, jotta koulutuksessa voidaan yhtäältä opettaa argumentoinnin teoriaa ja käytäntöjä, ja toisaalta tieteenalankohtaista sisältötietoa, tiedonmuodostuksen kannalta sopivan argumentoinnin keinoin.

Huomattavaa on, että opiskelijan hyvä sisältötieto esimerkiksi fysiikassa ei automaattisesti tarkoita hyviä argumentointitaitoja samassa aiheessa, mutta sisältötiedon ja sen argumentoinnin samanaikainen harjoittelu voi johtaa myös parempaan sisältötiedon oppimiseen (Rapanta ym., 2013). Monista lupaavista mahdollisuuksista huolimatta argumentoinnin painottaminen opetuksessa ei ole ongelmatonta. Se muun muassa edellyttää argumentin ja sen osatekijöiden tunnistamista, minkä helpottamiseksi niitä usein kuvataan erilaisten argumentointimallien avulla. Nämä mallit määrittävät, miten argumenttia kuvataan, mikä argumentti on ja mitä tulisi huomioida sen muodostamisessa ja arvioinnissa. Tässä artikkelissa kuvataan erilaisia luonnontieteiden opetuksessa ja sen tutkimuksessa hyödynnettyjä argumentointimalleja tavoitteena hahmottaa millaisen perustan ne muodostavat fysiikassa käytettävän argumentoinnin ymmärtämiseksi. Lisäksi tarkastellaan miten hyvin ne vastaavat fysiikan tiedon esittämisen vaatimuksia tiedon luonteen ja tiedon muodostuksen näkökulmista. Tämän tarkastelun tavoitteena on siis taustoittaa ja luoda perusteita fysiikan aineenopettajakoulutuksessa hyödynnettävän argumentointimallin kehittämiselle. Tässä vaiheessa mallia ei kiinnitetä tiettyyn vuorovaikutustapaan (suulliseen tai kirjalliseen), vaan tarkastelu keskittyy fysiikan tiedon argumentoinnin vaatimuksiin aineenopettajankoulutuksen kontekstissa, jossa keskeisenä tavoitteena on oppia hahmottamaan fysiikan sisältötiedon kokonaisuus opetettavassa muodossa. Kontekstiksi on valittu aineenopettajakoulutus, sillä argumentoinnilla voidaan nähdä hieman erilaisia tavoitteita kokonaan uuden tiedon luomisessa (tutkimus) ja jo olemassa olevan tiedon opiskelussa (opetus) (ks. esimerkiksi Wohlrapp, 2014).

\section{Teoriatausta}

Argumentointitutkimuksen kenttä on laaja ja jossain määrin myös ristiriitainen. Tutkijoilla ei ole yhtenevää näkemystä argumentoinnin perusrakenteesta, sen tavoitteista, edellytyksistä tai mahdollisuuksista (Wohlrapp, 2014). Argumentointitutkimuksen yksi tunnetuimmista teoksista on Stephen Toulminin kirja "The Uses of Argument" (1957/2003), jota on käytetty laajasti argumentointitutkimuksen lähtökohtana. Toulmin näyttää olevan keskeinen lähtökohta myös, kun tiedeopetuksessa on painotettu argumentointia ja tutkittu sen vaikuttavuutta. On kuitenkin syytä huomata, että Toulminin argumentointimallin lähtökohtana ovat olleet oikeuden istuntojen perustelut ja Toulminin kirja käsittelee tiedon puolustamista tai tiedon oikeutusta (engl. justification). Toulmin ei siis tarkastele kysymystä siitä, mitä tieto on tai miten se muodostuu luonnontieteissä. Toulminin näkemyksessä tieto on implisiittistä, yhteisön tai konventioiden luomaa. Toulminin argumentointimalli toimii kuitenkin hyvin siinä tarkoituksessa, johon se on alun perin tarkoitettu: jos on 
punnittava päätöstä kahden uskottavan vaihtoehdon välillä, Toulminin argumentointimallia voi käyttää vaihtoehtojen arvioinnissa.

On siis aiheellista kyseenalaistaa Toulminin argumentointimallin käyttö luonnontieteiden tiedonmuodostuksen perustana. Lisäksi Toulminin argumentointimallia kohtaan on esitetty yleisempääkin kritiikkiä. Esimerkiksi Wohlrapp (2014) huomauttaa, että Toulminin mallia voi kritisoida sen yleisyyden puutteesta. Toulmin ei nimittäin esitä argumentoinnin käytäntöjen kokonaisuutta, vaan ainoastaan sitä osaa argumentoinnista, joka koskee väitteiden puolustamista ja tiedon oikeutusta. Toulminin argumentointimallia pitäisi hänen näkemyksensä mukaan esimerkiksi laajentaa käsittämään myös argumentatiivinen induktiivinen tai deduktiivinen päätelmä. Böttcher ja Meisert (2011) myös huomauttavat, että Toulminin malli ei toimi pidempien argumenttirakenteiden analyysissä. Sandoval ja Millwood (2005) katsovat toulminlaisen rakenneanalyysin riittämättömäksi erityisesti sen vuoksi, koska se ei ota kantaa itse väitteiden järkevyyteen.

Kokonaisvaltaisempi ymmärrys argumentoinnista voidaan Wohlrappin (2014) mukaan saavuttaa huomioimalla argumentoinnin taustalla oleva tietoperusta, jota hän kutsuu termillä episteeminen teoria. Argumentointi riippuu henkilöiden tietoperustasta, joka määrittää mitkä ovat relevantteja argumentoinnin kohteita, hyväksyttäviä päättelyn muotoja ja tarkoituksenmukaisia evidenssilähteitä argumentoinnin myötä kehittyvälle uudelle tiedolle. Tarve argumentoinnille Wolhlrappin (2014) mukaan tarkoittaa, että tietoperusta on joiltain osin riittämätön käsillä olevan ongelman ratkaisemiseksi, minkä vuoksi sitä tulee laajentaa tai muokata niin sanotuksi teittiseksi teoriaksi (engl. thetic theory). Tässä teorian muodossa tieto on epävarmaa, alustavaa ja kehittyvää pitäen sisällään erilaisia ratkaisuyrityksiä ja niiden arvioita. Sekä yritykset että niiden arvioit tyypillisesti nojautuvat aikaisempaan tietoperustaan, jolloin myös teittinen teoria on aikaisemmasta tietoperustasta riippuva uuden tiedon kokonaisuus. Kun teittinen teoria kehittyy sellaiseksi, että sen avulla voidaan ratkaista aikaisemmin ratkaisematon ongelma, se voi vakiintua ja muuttua aikaisemman tietoperustan uudeksi muodoksi. Huomionarvoista on, että teittisyyden kautta argumentoinnin alainen tieto nojautuu aina aikaisempaan tietoperustaan, minkä vuoksi argumentoinnissa tulisi huomioida tiedon rakentumisen perusteet ja lähtökohdat, joihin esimerkiksi Toulminin argumentointimallissa ei oteta eksplisiittisesti kantaa.

\section{Fysiikan tiedon argumentoinnin tausta}

Tieteenalakohtaisesta tiedosta voidaan tunnistaa tiedeyhteisön konsensustieto (engl. secure knowledge) ja muotoutumassa oleva tieto (engl. sciencein-the-making), joka vielä jakaa yhteisön jäsenten näkemykset keskenään ristiriitaisiin lopputuloksiin (Driver, Newton, \& Osborne, 2000). Muotoutumassa oleva tieto voi muuttua konsensustiedoksi tiedeyhteisön argumentoinnin seurauksena. Konsensuksen saavuttamisen jälkeen argumentointiprosessi muodostaa tiedolle eräänlaisen kuvauksen. Tämä kuvaus pitää sisällään perusteltuja väittämiä, joiden lopputulemana tieto näyttäytyy teorioiden, mallien, periaatteiden ja lakien muodoissa. Lisäksi kuvaukseen kiinnittyy tietoa tarkastelukohteen olioista, niiden ominaisuuksia, ominai- 
Ainedidaktiikka 5(1) (2021)

suuksien kuvaavista käsitteistä ja näiden välisistä relaatioista sekä relaatioiden pätevyysalueista. Niinpä konsensukseen johtaneet argumentointiprosessit luovat tiedolle ja sen luonteelle monia merkityksiä. Nämä merkitykset tulisi huomioida koulutustoiminnassa, etenkin jos koulutus pyrkii tähtäämään tieteenalakohtaisen tiedon luonteen syvälliseen hallintaan ja siitä kumpuavaan sivistykseen. Nämä prosessit ovat kuitenkin harvoin, jos koskaan, formaalin opetustoiminnan päätavoitteena, mikä näkyy vakiintuneen sisältötiedon vahvana painotuksena useiden koulutustasojen opetussisällöissä (Newton, Driver \& Osborne, 1999).

Fysiikan tiedolle luonteenomaista on normatiivisuus ja hierarkkisuus. Tämä näkyy siinä, että fysiikan käsitteiden merkitys rakentuu osana käsitteiden kokonaisuutta. Tällaiseen näkemykseen viitataan yleensä ilmaisulla tieto systeeminä (engl. knowledge as system). Tässä näkemyksessä fysiikan tieto rakentuu käsitteellisenä systeeminä, jossa relationaaliset rakenteet käsitteiden välillä ovat keskeisessä asemassa. Fysiikan tapauksessa nämä relaatiot ovat fysiikan lakeja. Tähän tapaan kuvailtu fysiikan tiedon luonne on tunnistettu fysiikan tiedon oppimisen keskeiseksi haasteeksi (Koponen \& Kokkonen, 2014).

Fysiikan opiskelijoille jää perus- ja aineopinnoista usein irrallinen ja sirpaleinen kuva fysiikasta kokonaisuutena (Mäntylä \& Nousiainen, 2014; Nousiainen, 2013). Aineenopettajankoulutuksessa fysiikan aineenhallinnan tavoitteena on laajojen kokonaisuuksien hahmottaminen, tieteellisen tiedon luonteen ymmärtäminen ja tieteellisesti pätevän perustelun oppiminen (Nousiainen, 2017; Mäntylä \& Nousiainen, 2014). Siispä myös niiden harjoitteluun olisi erikseen panostettava. Fysiikan opetuksessa ja opiskelussa on siten korostettava loogista, koherenttia, analyyttistä ja kriittistä ajattelua sekä argumentointia, sillä ne ovat kiistattomia piirteitä fysiikassa oppiaineena (Sandoval \& Millwood, 2007). Fysiikan tiedonmuodostuksen luonne ja tiedon sisältö määrittävät vahvasti sen, millainen argumentointi on pätevää ja kussakin tilanteessa riittävää.

\section{Argumentoinnin rooli fysiikan opetuksessa ja opetuksen tutkimuk- sessa}

Jiminéz-Aleixandre ja Erduran (2008) näkevät argumentoinnilla monenlaisia potentiaalisia hyötyjä tiedeopetuksessa. Argumentoinnin voidaan sanoa tukevan muun muassa

- kognitiivisia ja metakognitiivisia prosesseja,

- kommunikaatiotaitojen ja kriittisen ajattelun kehittymistä,

- tieteellisen lukutaidon kehittymistä,

- tieteen kielellä kommunikoimista,

- kehittymistä tiedon episteemisten kriteerien arvioinnissa ja

- päättelyn kehittymistä, erityisesti teorioiden tai rationaalisten kriteerien valinnassa.

Fysiikan opetuksen tutkimustraditiossa osin samoihin hyötyihin on pyritty muun muassa vahvistamalla opiskelijoiden käsitteellistä osaamista, ongelmanratkaisutaitoja ja tieteenalakohtaista ajattelua (Docktor \& Mestre, 2014; McDermott, 2001; Crouch \& Mazur, 2001). Vaikka argumentointi 
terminä esiintyy varsin harvoin fysiikan tutkimusperustaisten opetusmenetelmien kuvauksissa (Meltzer, \& Thornton, 2012), se on nähtävissä pyrkimyksinä ohjata opiskelijoita mahdollisimman selkeään päätelmiensä esittämiseen, ristiriidattomien päättelyketjujen tekemiseen ja yhteisölliseen tiedonmuodostukseen. Nämä ovat keskeisiä tunnuspiirteitä luonnontieteille ominaiselle argumentoinnille, minkä vuoksi fysiikan tutkimusperustainen opetus voidaan nähdä lupaavana lähtökohtana argumentoinnin painottamiselle, erityisesti yliopistotasolla.

Lisäksi fysiikan opetuksen tutkimuksessa on kiinnitetty huomiota opiskelijoiden näkemyksiin fysiikan luonteesta, eli millaista fysiikan tieto on ja mitä sen osaaminen edellyttää (Redish, Saul \& Steinberg, 1998). Näiden näkemysten on havaittu olevan yhteydessä opiskelutapoihin siten, että opiskelijat, joille fysiikka näyttäytyy kokoelmana irrallisia luonnonlakeja, pyrkivät todennäköisemmin opettelemaan ulkoa opiskeltavia sisältöalueita. Heidän on myös havaittu pystyvän soveltamaan heikosti tietojaan uusiin tilanteisiin. Opiskelijat, jotka hahmottavat fysiikan koherenttina tietosysteeminä irrallisten luonnonlakien sijasta, pyrkivät usein ymmärtämään opiskeltavan sisältötiedon syvällisemmin ja he pystyvät soveltamaan tietojaan monipuolisesti. (Perkins, Adams, Pollock, Finkelstein \&Wieman, 2005; Redish \& Steinberg, 1999) Niinpä opiskelutapojen ohjaaminen ulkoluvusta kohti ymmärrystä on tärkeää. Sen saavuttamiseksi argumentoinnin painottaminen vaikuttaa lupaavalta menetelmältä, sillä argumentoinnin myötä osaamisen painopiste siirtyy luontevasti kohti laajempien tieto- ja päättelykokonaisuuksien hallintaa. Näistä potentiaalisista hyödyistään huolimatta fysiikan tiedon luonteeseen perustuvia argumentointimalleja tutkimuskirjallisuudesta ei juurikaan löydy eikä argumentointia merkittävästi painoteta fysiikan opetuksessa. Seuraavassa esitetty teoriakatsaus luo edellytyksiä sen hahmottamiseksi, millaisia argumentointimalleja olemassa oleva kirjallisuus tarjoaa ja edelleen sen pohtimisessa, miten hyvin ne tavoittavat erityisesti fysiikan tiedon esittämisen keskeiset näkökulmat, ja miten hyvin kyseiset mallit siten ovat käytettävissä fysiikan tiedon argumentoinnissa.

\section{Teoriakatsauksen metodin kuvaus}

Esitämme tässä artikkelissa katsauksen luonnontieteiden opetuksen tutkimuksessa käytettyihin keskeisiin tapoihin kuvata ja analysoida argumentointia. Tämän katsauksen ei ole tarkoitus olla kaiken kattava ja laaja, sillä kirjallisuuden kenttä on hyvin lavea. Tämän vuoksi katsaus on tarkoituksella rajattu muutamaan keskeiseen ja tavoitteiltaan erilaiseen argumentointimalliin. Katsaukseen otetut argumentointimallit on valittu sillä perusteella, että niitä kaikkia voidaan soveltaa argumentoinnin analysoitiin fysiikan opetuksessa, mutta niiden lähestymistapa on keskenään erilainen, ja niitä voidaan soveltaa erityyppisten aineistojen analysoitiin (suullinen tai kirjallinen). Tämän suppean metatutkimuksen avulla voimme kuitenkin osoittaa eroja ja kehityskohteita argumentointimalleissa, sekä ymmärtää paremmin fysiikan opetuksen tavoitteiden kannalta oleellisia asioita argumentoinnista ja sen tutkimuksesta. Tässä artikkelissa analysoidaan ja vertaillaan neljää eri argumentointimallia. 


\section{Ainedidaktiikka 5(1) (2021)}

1. Toulminin kirja "The Uses of Argument" (1957/2003) esittää yleisen, tieteenalasta riippumattoman argumentointimallin, johon lähes kaikki myöhemmin julkaistut argumentointimallit nojaavat.

2. Böttcherin ja Meisertin artikkeli "Argumentation in Science Education: A Model-based Framework" (2010) painottaa mallien roolia fysiikan tiedon rakentumisessa ja argumentoinnissa.

3. Sampsonin artikkelit "Argument-Driven Inquiry as a Way to Help Students Learn How to Participate in Scientific Argumentation and Craft Written Arguments: An Exploratory Study" (Sampson, Grooms \& Walker, 2011) ja "Science Teachers and Scientific Argumentation: Trends in Views and Practice" (Sampson \& Blanchard, 2012) esittävät argumentointimallin luonnontieteiden koulukokeellisuuden näkökulmasta.

4. Sandovalin artikkeli "Conceptual and Epistemic Aspects of Students' Scientific Explanations" (2003) ja Sandovalin ja Millwoodin artikkelit "The Quality of Students' Use of Evidence in Written Scientific Explanations" (2005) ja "What can argumentation tell us about epistemology?" (2007) esittävät analyysitavan argumentin käsitteelliselle ja episteemiselle laadulle.

\section{Argumentointimallien ja analyysitapojen vertailu}

Esitämme seuraavassa yllä esitettyjen argumentointimallien ja analyysitapojen taustat, tavoitteet ja tarkoituksen, mahdollisen rakenteen ja erityispiirteet.

\section{Toulminin yleinen argumentointimalli}

Toulminin työn $(1957 / 2003)$ taustalla on ollut pyrkimys muodostaa mahdollisimman yleinen ja tieteenalasta riippumaton argumentointimalli erilaisten argumenttien arvioinnin jäsentämiseksi. Malli perustuu ajatukseen, jonka mukaan on mahdollista tunnistaa yleiset, argumentointitilanteesta riippumattomat (engl. field-invariant) vaiheet, joiden kautta argumentit kehittyvät, vaikka tilanne- tai alakohtaiset (engl. field-dependent) tekijät vaikuttavat argumentin muotoutumiseen ja sen arviointiin. Toulmin pohtii yleisiä argumentoinnin kriteereitä siitä näkökulmasta, mitkä argumentoinnin piirteet ovat alasta riippumattomia. Esimerkkinä hän esittää oikeuden istunnon, josta voidaan tunnistaa juridinen prosessi ja rationaalinen prosessi. Yksi ilmiselvä erityispiirre juridiseen argumentointiin liittyy. Siinä on suuri vaihtelevuus sen suhteen, mikä evidenssi on missäkin tapauksessa relevanttia. Jokaisesta tapauksesta voidaan kuitenkin löytää samankaltainen rakenne: alkutilanne, todisteiden esittäminen ja päätös tuomiosta. Tästä argumentoinnin rakenteen yleisestä samanlaisuudesta on esitetty yleisimmin tunnettu Toulminin ajatus, joka tunnetaan englanniksi nimellä Toulmin's argument pattern (TAP). Tämä yksinkertaistettu malli kuvailee hyvin yleisellä tasolla argumentin rakennetta ja argumentin osia 
(katso kuva 1). Toulmin kuvailee argumenttia organismiksi, jolla on sekä laajempi rakenne, anatomia, että hienosyisempi, fysiologinen, rakenne. Toulminin työ keskittyy lähinnä näitten hienosyisten argumenttien rakenteen arviointiin. Toulminin argumentointimallia voi käyttää sekä suullisen että kirjallisen aineiston analysointiin, mutta on huomattavaa, että analyysiyksikkö on korkeintaan muutaman virkkeen mittainen (ks. esimerkki kuvan 1 jälkeen).

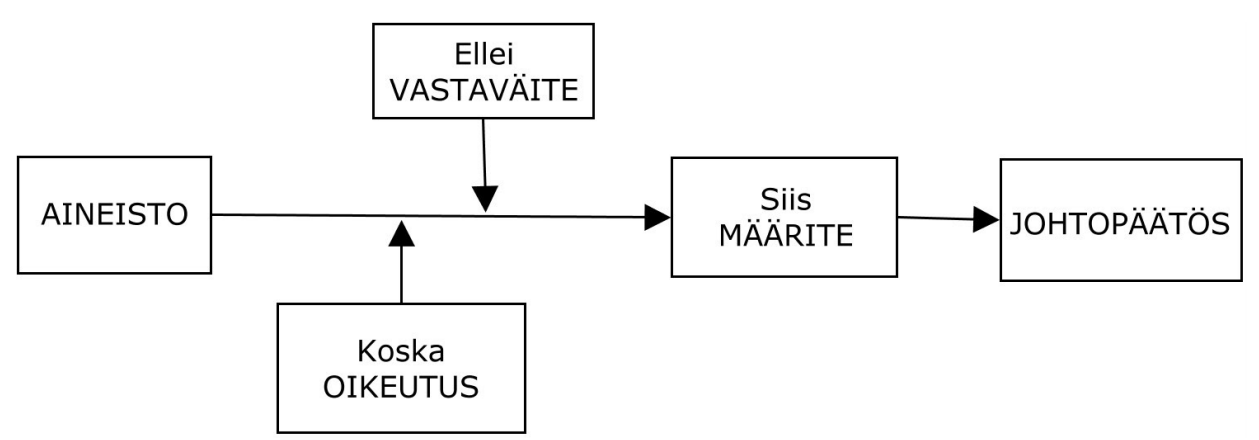

Kuva 1: Toulmin esittämä argumentin perusrakenne muodostuu aineistosta (engl. data), oikeutuksesta (engl. warrant), vastaväitteestä (engl. rebuttal), määritteestä (engl. qualifier) ja johtopäätöksestä.

Toulmin argumentin perusrakenne lähtee liikkeelle siitä, että argumentoitavasta asiasta on olemassa jotain aineistoa. Fysiikan kontekstissa aineisto voisi esimerkiksi olla seuraava kokeellinen havainto: sarjaan kytketyt samanlaiset lamput palavat keskenään yhtä kirkkaasti. Tälle tiedolle voidaan esittää fysiikan teorian mukainen oikeutus: lamppujen kirkkaus määräytyy Joulen lain mukaisesti niiden kuluttaman tehon perusteella. Oikeutusta saattaa heikentää vastaväite, joka fysiikan näkökulmasta voisi liittyä kyseisen tilanteen idealisointeihin tai lain pätevyysalueisiin: lamput eivät ole ohmisia vastuksia, sillä niiden lämpeneminen vaikuttaa johtavuuteen. Vastaväite voidaan kuitenkin ottaa huomioon määritteellä: sähkövirrat ovat niin pieniä, että lamppujen lämpeneminen ei merkittävästi vaikuta niiden johtavuuteen. Näiden tietojen pohjalta voidaan tehdä johtopäätös, joka esimerkkitapauksessa olisi: sarjaan kytkettyjen samanlaisten lamppujen tehot ovat siten yhtä suuret.

Yllä esitetty esimerkki vahvistaa Toulmin mallin hyvän puolen eli yleisyyden siinä mielessä, että sen argumentin perusrakenne toimii tieteenalasta ja kontekstista huolimatta. Toisaalta juuri tämä yleisyys on myös mallin suurin heikkous. Toulminin yleistä mallia ei voi sellaisenaan suoraan käyttää argumentin toimivuuden analysointiin missään kontekstissa. Fysiikan kontekstiin sijoitettu esimerkki osoittaa sen, että Toulminin argumenttirakenne mahdollistaa vain hyvin yksinkertaisten väitteiden perustelun, kun taas esimerkiksi juuri fysiikassa riippuvuudet ja relaatiot voivat olla hyvinkin monimutkaisten perusteluketjujen tuloksia. Argumentin analysointiin tarvitaan siis aina kyseiseen tieteenalaan sovelletut argumentin analyysikriteerit tai jopa mahdollisesti kokonaan uudenlainen analyysikehikko. Toulminin argumenttimalli ei ota huomioon tiedon oikeellisuutta eli sen avulla ei voi suoraan, ilman tulkintaa arvioida esimerkiksi virheellisiä perusteluketjuja. Toulminin argumenttimalli on kuitenkin sen yleisyyden ja muokattavuuden vuoksi laajasti hyödynnetty 
ja sen perusteella on tehty useita uusia avauksia eri tieteenaloilla (ks. esim. Jiminéz-Aleixandre \& Erduran, 2008; Sampson \& Clark, 2008; Kelly, Regev \& Prothero, 2008). Tosin Toulminin malliin suoraan nojautuvaa fysiikan tiedon argumentointiin liittyvää tutkimusta ei juurikaan ole tehty, mutta Toulminin malli on siitä huolimatta toiminut tausta-ajatteluna monessa työssä (ks. esim. Sampson, 2011; Sampson \& Blanchard, 2012).

Toulminin mallin pohjalta on muodostettu erilaisia argumentoinnin analyysikriteereitä, jotka ovat jossain määrin mahdollistaneet argumentoinnin määrän ja laadun arvioimisen luokkahuoneolosuhteissa (ks. Erduran, ym., 2004). Kriteerien käyttöä on varjostanut vaikeus erottaa argumentin eri rakenneosaset esimerkiksi oppilaiden välisestä vuoropuhelusta. Toisaalta näiden ongelmien ratkaisemiseksi on tunnistettu tehtäväja dialogityyppejä, jotka todennäköisemmin ohjaavat oppilaita argumentatiiviseen vuorovaikutukseen Tällainen kehitys voidaankin nähdä Toulminin tunnistaman argumentinperusrakenteen jatkokehittämiseen liittyvän tutkimustyön ansiona (esim. Erduran, ym., 2004).

\section{Böttcherin ja Meisertin malleihin perustuva argumentoinnin analyy- simalli}

Böttcher ja Meisert (2011) esittävät teoreettisen taustan malliperustaiselle argumentoinnin viitekehykselle, jonka tavoitteena on kuvata ja arvioida tiedeopetuksen argumentatiivista prosessia. Ajatus perustuu yleiseen näkökulmaan malleista kognitiotieteessä ja tieteen filosofiassa. Tässä näkemyksessä argumentin ymmärtäminen liittyy teoreettisen mallin sopivuuteen tietyn ilmiön selittämisessä. Argumentointi on siten prosessi, joka yhtäältä tarkastelee kriittisesti mallia suhteessa vaihtoehtoisiin malleihin ja toisaalta pyrkii esittämään mallien samanlaisuuden empiiriseen dataan perustuen. Malleihin perustuva argumentoinnin analyysimalli näkee argumentoinnin vertailuprosessina. Malliperustaisen argumentoinnin tavoitteena ei siten ole yksittäisen väitteen puolustaminen, vaan mallien uskottavuuden validointi.

Böttcher ja Meisert (2011) väittävät, että keskittymällä malleihin yksittäisten väitteiden sijaan voidaan välttää tiettyjä Toulminin argumentoinnin analyysimalliin liittyviä ongelmia ja jopa selittää, miksi kyseisiä ongelmia syntyy. Böttcherin ja Meisertin argumentoinnin analyysimallia on hyödynnetty fysiikan tehtäviin liittyvien luokkahuonekeskustelujen analysoinnissa. Tämä analyysimalli erottelee malleihin perustuvan argumentoinnin neljä tasoa.

1. Mallin taso (sisältää uuden mallin konstruoinnin ja muuntelun). Mallin tasolla tunnistetaan tavoitteena oleva mallit ja niiden oleelliset piireet, ja taustalla olevat mallit ja niiden oleelliset piirteet.

2. Argumentoinnin osapuolten taso. Argumentointitapahtuman osallistujien eli henkilöiden tunnistaminen. Tämän tason mukaan ottaminen mahdollistaa analysoitavien yksilöiden selitysmallien kehityksen seuraamisen.

3. Aineiston taso. Aineiston tasolla tunnistetaan olemassa oleva aineisto, jota mallien perusteluissa, arvioinnissa ja 
vertailuissa tarvitaan ja käytetään, tehdään mahdollinen aineiston strukturointi ja visualisointi.

4. Prosessin taso. Prosessin tasolla tunnistetaan argumentit mallien loogisen koherenssin puolesta tai vastaan ja mallien ennustettavuuden ja empiirisen datan puolesta tai vastaan sekä argumentit kilpailevien mallien loogisen koherenssin puolesta tai vastaan ja kilpailevien mallien uskottavuuden ja empiirisen data puolesta tai vastaan.

Böttcherin ja Meisertin analyysimalli tarkastelee siis hyvin hienosyisesti sitä, miten argumentoinnissa käytetään malleja, mitä malleja käytetään, kuka kyseisiä malleja käyttää, mihin aineistoon tarkasteltavat mallit perustuvat ja millaisiin prosesseihin mallit voidaan liittää. Analyysimallissa viimeinen taso eli prosessin taso keskittyy nimenomaan mallin arvioimiseen ja argumentointiin. Arvioitavassa aineistossa jokainen proseduraalinen askel, joka voidaan tulkita perusteluksi joko sopivan mallin puolesta tai vastaan, on argumentti.

Malliperustaisen argumentoinnin osaamisen edellytyksenä voidaan pitää yleistä taitoa argumentoida, argumentoinnin prosessin ymmärtämistä sekä tarpeellisia tietoja malleista ja datasta, joita ilman argumentointi ei onnistuisi. Böttcher ja Meisert tuovat useassa kohdassa selvästi esiin erot malliperustaisen argumentoinnin analyysin ja Toulminin argumenttianalyysin välillä. Malliperustainen argumenttien analyysimalli tuo hyvin hienosyisen, mutta työlään tavan argumentoinnin tarkasteluun selitysmallien vertailuun perustuen. Tämän vuoksi Böttcherin ja Meisertin analyysimalli tavoittaa hyvin oleellisia piirteitä nimenomaan fysiikan tiedon rakentumisessa ja perustelussa. Malliperustaisen analyysimallin avulla voidaan erotella argumentin sisältöön liittyviä piirteitä, esimerkiksi analysoida selitysmallien kehittymiseen liittyviä oppimisprosesseja. Tässä analyysitavassa argumenttien laatua voidaan arvioida suhteessa oppimisen tavoitteena oleviin selitysmalleihin, mutta se ei aivan suoraan ota kantaa argumenttien episteemisiin kriteereihin.

\section{Sampsonin argumentointimalli koulukokeellisuudelle}

Koulukokeellisuus on luonteva ympäristö argumentoinnin painottamiseksi, sillä se mahdollistaa empirian ja teorian välisen vuoropuhelun luonnontieteiden opetuksessa. Kuitenkin perinteiset reseptinomaiset kokeelliset työt tukevat vain vähän luonnontieteille ominaisten argumentointitaitojen kehittymistä (Sampson ym., 2011). Tämän vuoksi on kehitetty argumentointia painottava koulukokeellisuuden opetusmenetelmä, Argument-Driven Inquiry (ADI). Tämä opetusmenetelmä nojautuu kuvassa 2 esitettyyn argumentointimalliin ja sen lähtökohtana on ollut Toulminin yleinen argumentointimalli. Sampsonin mallissa luonnontieteellinen argumentti koostuu väitteestä, evidenssistä ja perusteluista ${ }^{2}$ ja sitä on hyödynnetty kirjallisten ja suullisesti esitettyjen argumenttien arvioinnin perustana (ks. Sampson ym., 2011; Sampson \& Blankhard, 2012).

\footnotetext{
${ }^{2}$ Sampsonin ym. artikkeleissa argumentin osatekijöiden termit vaihtelevat: reasoning rationale; the claim - explanation (vrt. Sampson ym., 2011; Sampson \& Blanchard, 2012; Sampson \& Clark, 2008), minkä vuoksi tässä artikkelissa esitetyt käännökset tähtäävät temaattiseen vastaavuuteen.
} 


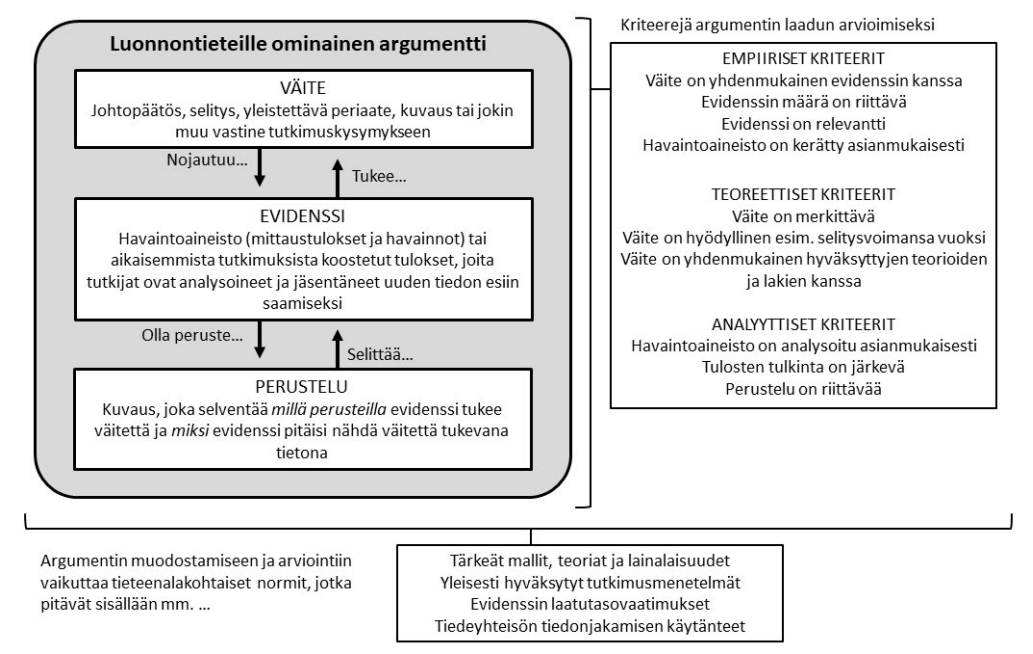

Kuva 2. Sampsonin malli argumentista ja argumentoinnista luonnontieteissä. Suomennus mukailee eri artikkeleissa esitettyjä osatekijöitä (Sampson \& Clark, 2008; Sampson. ym., 2011; Sampson \& Blanchard, 2012; Sampson, Enderle \& Grooms, 2013).

Mallissa väite nähdään tutkimustyön lopputuloksena, joka voi olla päteväksi osoitettu matemaattinen kaava, johtopäätös, selitys, tutkittavan ilmiön taustalla olevan mekanismin kuvaus tai jokin muu vastaus tutkimuskysymykseen. Evidenssi viittaa väitettä tukevaan havaintoaineistoon ja se voi pitää sisällään mittausarvoja tai muita ilmiöstä tehtyjä havaintoja, jotka luovat perustan väitteen paikkansa pitävyydelle. Havainnot ja mittausarvot muodostavat evidenssin, kun ne on analysoitu, jäsennetty tai muutoin tulkittu (esimerkiksi aikariippuvuus, ryhmien väliset erot tai muuttujien väliset yhteydet) (ks. Sampson, Grooms \& Walker, 2011; Sampson \& Blanchard, 2012). Mallin perusteluosa selventää, millä perusteella argumentin evidenssi tukee väitettä ja tähdentää, miksi juuri kyseinen evidenssi on keskeistä väitteen paikkansa pitävyyttä arvioitaessa. Täten perusteluosassa esitetään tarvittavat taustaoletukset, periaatteet tai käsitteet, jotka muodostavat loogisen ja perustellun yhteyden väitteen ja evidenssin välille.

Argumentin osatekijöiden lisäksi Sampsonin mallissa esitetään empiiriset, teoreettiset ja analyyttiset kriteerit argumentin vahvuuden arvioimiseksi. Empiiriset kriteerit tarkastelevat väitteen ja evidenssin ristiriidattomuutta, evidenssin riittävyyttä, relevanssia ja laatua. Teoreettiset kriteerit tarkastelevat väitteen merkittävyyttä, hyödyllisyyttä ja yhdenmukaisuutta suhteessa tieteenalan sisältötietoon. Analyyttiset kriteerit tarkastelevat havaintoaineiston käsittelyä, tulosten tulkintaa ja niiden taustalla olevan päättelyn mielekkyyttä. Sampsonin mallissa tuodaan esille, että argumentin osatekijöiden ja arviointikriteerien täsmällisemmät sisällöt ovat tieteenalakohtaista. Toisin sanoen ne riippuvat tieteenalan tavoitteista, teorioista, malleista, lainalaisuuksista ja niiden taustalla olevista vakiintuneista tutkimusmenetelmistä, ja formaaleista ja informaaleista vuorovaikutustavoista. 
Fysiikan näkökulmasta Sampsonin malli on lupaava. Mallista välittyy yleispätevä kuvaus argumentista ja sen osatekijöistä sekä niiden sisällöistä ja suhteista. Lisäksi se osoittaa fysiikan kannalta keskeisiä näkökulmia argumentin vahvuuden arvioimiseksi. Toisaalta argumentin osatekijöiden rajaus on ongelmallinen. Etenkin evidenssin sitominen vahvasti empiriaan, kokeelliseen havaintoaineistoon, rajoittaa mallin hyödyntämistä fysiikan teoreettisempien tehtävien parissa. Esimerkiksi, jos oppilasta pyydetään ennustamaan eri massaisten mutta muuten samanlaisten pallojen putoamisaika, hänen on vaikea asettaa vastauksensa sellaisen argumentin muotoon, jonka evidenssi edellyttää viittaamista empiirisiin havaintoihin, joita tehtävänannossa ei esitetä.

Toisaalta fysiikan teoriatiedon argumentointi Sampsonin malliin nojautuen on hankalaa. Mallia pitäisi laajentaa siten, että evidenssiksi luettaisiin myös teoreettisia tietorakenteita, kuten fysiikan käsitteitä, lakeja, malleja ja teorioita. Näihin nojautuen fysiikan sisältötiedon deduktiivisen käytön ja esittämisen voisi jäsentää argumentin muotoon esimerkiksi teoreettisissa ongelmanratkaisutehtävissä. Teoriaan nojautuvan evidenssin perusteluosa voisi pitää sisällään lakien tai mallien pätevyysalueiden ja sovellettavuuden tarkastelua. Kokonaisuutena argumentin muodossa esitetty ratkaisu voisi lisätä annetun vastauksen uskottavuutta, sillä se sisältäisi kantaaottavan väitteen, fysiikan teoriatietoon nojautuvan evidenssin ja perusteet teoriatiedon sovellettavuudelle.

Sampsonin mallin arviointikriteerit näyttäytyvät fysiikan opettamisen näkökulmasta haastavina. Esimerkiksi evidenssin riittävyyden määrän täsmällinen ja yleispätevä arviointi on hyvin vaikeaa, ellei jopa mahdotonta. Vaikka intuitiivisesti on selvää, että enemmän havaintoaineistoa muodostaa vakuuttavamman evidenssin esitetylle väitteelle, on hankala sanoa missä riittävän ja riittämättömän evidenssin raja kulkee. Tällaisen rajan määrittäminen on usein tapauskohtaista ja edellyttää usein seikkaperäistä ilmiön ja sen tutkimiseen käytettävien työkalujen tuntemista. Toisin sanoen Sampsonin mallin arviointikriteerien soveltaminen fysiikan opetukseen vähintäänkin haastaa nykyiset opetussisällöt useilla eri koulutustasoilla.

\section{Sandovalin ja Millwoodin analyysimalli argumentin käsitteelliselle ja episteemiselle laadulle}

Sandoval (2003) ja Sandoval ja Millwood (2005, 2007) hakevat analyysillaan vastausta siihen, onko argumentti kokonaisuutena pätevä. Analyysi keskittyy ensisijaisesti argumentin sisältöön ja perusteluun; argumentin rakenteeseen otetaan kantaa epäsuoremmin. Tieteenala ja käsitelty aihe vaikuttavat merkittävästi siihen, millainen argumentti on vakavasti otettava. Analyysin kriteerit ovat siten tieteenala- ja aihekohtaiset ja ne on muokattava sopimaan analysoitavaan tekstiin. Tutkijan on aluksi määriteltävä itse tehtäväkohtaisesti hyvän vastauksen piirteet: millaisia ovat tehtävälle relevantit yläkäsitteet tai väitteet, näihin kuhunkin liittyvät prosessit tai ilmiöt ja väitteitä tukeva data. Argumentin käsitteellinen ja episteeminen laatu analysoidaan näihin piirteisiin nojautuen. Aineistona on käytetty opiskelijoiden kirjallisia raportteja tutkimuksellisista tehtävistä. Raportteihin on voinut sisällyttää esimerkiksi kuvaajia ja taulukoita, jotka on analyysissa huomioitu osana argumenttia. 


\section{Ainedidaktiikka 5(1) (2021)}

Käsitteellisessä analyysissa tarkastellaan, 1) löytyykö argumentista olennaisimmat käsitteet, joiden puuttuminen johtaisi aukkoihin perusteluissa, 2) miten näihin käsitteisiin liittyvät olennaiset prosessit tai ilmiöt on identifioitu, kuvailtu tai selitetty; onko esimerkiksi asioiden väliset suhteet sanallistettu, ja 3) löytyykö argumentista relevanttia (kvalitatiivista tai kvantitatiivista) dataa perustelemaan esitettyjä väitteitä. Argumentti arvioidaan sen mukaan, kuinka hyvin se täyttää ennalta asetetut kriteerit. Käsitteellinen analyysi on samankaltainen kaikissa kolmessa artikkelissa. Episteeminen analyysi on olennainen osa Sandovalin ja Millwoodin analyysia. Käsitteellisessä analyysissa kysymys on, mitä tiedetään. Episteemisessä analyysissa pohditaan sitä, miten tiedetään mitä tiedetään. Analysoidaan siis sitä, miten käsitteet, väitteet ja data linkittyvät toisiinsa muodostaen uskottavan kokonaisuuden. Kaikissa kolmessa artikkelissa ollaan kiinnostuttu siitä, onko esitetty aineisto riittävää kunkin väitteen perusteluksi, onko ilmiö selitetty selkeästi syy-seuraussuhtein ja miten aineistoon on viitattu. Tämän analyysin painotus ja toteutus kuitenkin vaihtelevat.

Sandoval (2003) analysoi asiaa pilkkomalla opiskelijan tekstin palasiksi niin, että kukin yksittäinen väite, viitattu aineisto ja selitys ovat omina yksiköinään. Nämä esitetään numeroituina laatikoina ja laatikot yhdistetään nuolilla ottaen huomioon opiskelijan eksplisiittisesti esittämät syyseuraussuhteet (tavalliset nuolet) sekä implisiittisiksi jäävät mutta esitetyn kokonaisuuden kannalta olennaiset yhteydet (katkoviivanuolet; ks. kuva $3)$.
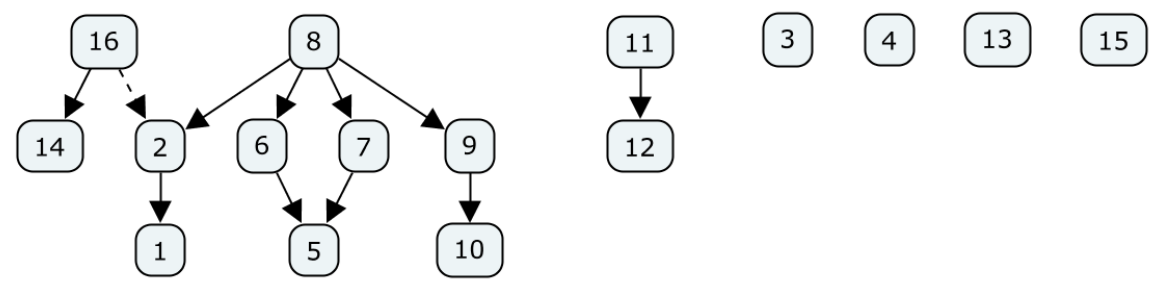

Kuva 3. Tekstissä esitettyjen syy-seuraussuhteiden erittely argumentin episteemisessä analyysissa, mukailtu Sandovalin kuvasta (2003). Kukin numeroitu laatikko kuvaa tekstinpätkää ja nuolet niiden keskinäisiä yhteyksiä: tavalliset nuolet tekstissä esitettyjä eksplisiittisiä ja katkoviivanuolet implisiittisiä yhteyksiä. Tämä esimerkki kuvaa argumenttia, jonka osat (yksittäiset väitteet, viitatut aineistot ja selitykset) on suureksi osaksi kytketty toisiinsa kokonaisuudeksi, mutta jossa osa esitetystä sisällöstä on muuhun kokonaisuuteen liittymätöntä (irralliset laatikot 3, 4, 13 ja 15). Lisäksi argumentissa on kahden kohdan syy-seurausketju (11 ja 12), joka ei linkity isompaan kokonaisuuteen. Kuvassa vasemmalla näkyvä kytkeytynyt osa argumentista näyttää, että sisältöjen välisistä suhteista valtaosa on sanallistettu suoraan; vain yksi syy-seuraussuhde (laatikoiden 16 ja 2 välillä) on implisiittinen. 
Sandoval ja Millwood (2005) liittävät argumentin rakenteen retoriikkaan, jonka he määrittelevät yleisön vakuuttamiseksi käytetyiksi keinoiksi, erityisesti miten argumentin osat on järjestetty ja miten niitä painotetaan. Tieteellisen argumentoinnin tavoitteena on luoda ilmiöille uskottavia selityksiä, joten retoriikka on heidän mukaansa olennainen osa tällaista argumentointia. Retoriikan tarkastelu, eli tässä miten dataan viitataan, tehdään käsitteellisen analyysin pohjalta kullekin pääväitteelle erikseen. Erityisesti huomio kiinnitetään siihen, mikä on selityksen retorinen taso: onko tekstissä vain mainittu esimerkiksi kuvaaja tai taulukko, onko kuvaajan sisältöä eritelty, kerrotaanko sisällön puoltavan tai kumoavan väite ja onko sisällön merkitystä tulkittu väitteen kannalta. Sandoval ja Millwood (2007) tarkastelevat, mihin perustelut pohjataan: esimerkiksi opettajan tai oppikirjan auktoriteettiin, faktaan, kausaaliseen selitykseen vai kokeelliseen aineistoon.

Analyysilla päästään hienosyisesti kiinni siihen, mitä käsitteellistä tietoa opiskelija osaa artikuloida, missä on vielä harjoiteltavaa, ja kuinka hyvin syy-seuraussuhteet hahmottuvat argumentissa erityisesti kokeelliseen dataan tukeutuessa. Tulokset viittaavat siihen, että dataa osataan käyttää monesti omia väitteitä muodostaessa, mutta niihin ei vedota perusteluissa tarpeeksi. Sandovalin ja Millwoodin malli sopii fysiikan argumenttien analysointiin erityisesti siinä tapauksessa, jos argumentissa on tarkoitus vedota kokeellisiin havaintoihin, taulukoihin ja kuvaajiin. Käsitteellisessä analyysissa dataan vetoaminen on olennaisessa osassa, ja sama toistuu retorisessa tarkastelussa. Fysiikan argumentoinnissa olennaista teorian tasoa ei ole huomioitu tässä mallissa eksplisiittisesti ollenkaan. Episteeminen analyysi argumentin rakenteelle ja sille, mihin perustelut pohjautuvat, toimivat niin kokeellisemman kuin teoreettisemmankin argumentin kohdalla.

\section{Keskustelu ja johtopäätökset}

Argumentointitutkimuksen kenttä on hyvin laaja ja monialainen. Voidaan jopa väittää, että argumentointitutkimuksen teoretisointi on edennyt niin pitkälle, että tarvitaan myös metatason tutkimusta (Wohlrapp, 2014). Kriittinen ajattelu, tiedon perustelutaidot ja argumentointi kuitenkin on tunnistettu tärkeiksi tulevaisuuden taidoksi ja sen vuoksi myös osaksi koulutustavoitteita (Fischer ym., 2014; Rapanta ym., 2013; Tiruneh ym., 2016). Argumentoinnilla on nähty olevan monia lupaavia hyötyjä tiedeopetuksessa, kuten esimerkiksi oppilaiden tieteellisen lukutaidon kehittyminen, tieteen kielen käytön oppiminen, episteemisen ajattelun kehittyminen ja rationaalisen päättelyn kehittyminen (Jiminéz-Aleixandre \& Erduran, 2008). Fysiikan opetuksen tutkimus keskittyy kuitenkin enemmän ongelmanratkaisutaitoihin ja tieteenalakohtaisen ajattelun vahvistamiseen (Crouch \& Mazur, 2001; Docktor \& Mestre, 2014; McDermott, 2001; Perkins ym., 2005). Argumentointitaitojen kehittyminen voidaan kuitenkin nähdä taustapyrkimyksenä, kun opiskelijoita ohjataan selkeään ja ristiriidattomaan päättelyyn. Argumentoinnin painottamista opetuksessa voidaan pitää lupaavana menetelmänä auttaa opiskelijoita laajempien tietorakenteiden hallinnassa. Tutkimuskirjallisuus ei juurikaan tunne näkemystä, jossa luonnontieteille ominainen argumentointi olisi laajemman fysiikan opetuksen tutkimustyön lähtökohta, vaikka 
siihen selvästi sisältyy potentiaalia. Tieteellisen tiedon ymmärtäminen ja argumentointi ovat keskeisiä oppimistavoitteita myös opettajankoulutuksessa, sillä argumentoinnin on havaittu tukevan myös tiedon kokonaisvaltaista ymmärtämistä (Mäntylä \& Nousiainen, 2014; Nousiainen, 2017; Vuola \& Nousiainen, 2020). Argumentoinnin painottaminen opetuksessa on siis selkeästi keskeinen ja tärkeä päämäärä, mutta käytännössä siihen sisältyy monenlaisia haasteita. Argumentoinnin painottaminen opetuksessa vaatii ensin argumentin ja sen osatekijöiden tunnistamista erilaisten argumentointimallien avulla, jotta voidaan määrittää, millainen argumentti on ja mitä sen muodostamisessa ja arvioinnissa tulisi huomioida. Tässä artikkelissa olemme koonneet yhteen neljä tavoitteeltaan erilaista fysiikan ja luonnontieteiden argumentoinnin kuvausta ja niitten analyysimallit osoittaaksemme näitten mallien erilaiset tavoitteet ja kootaksemme yhteen luonnontieteellisen tiedon argumentoinnin oleellisia näkökulmia.

Toulminin argumentointimalli on hyvin yleinen ja tieteenalasta riippumaton, joka tunnistaa argumentointiprosessin yleisen rakenteen. Toisaalta Toulminin malli ei lähtökohtiensa vuoksi ota kantaa väitteiden episteemiseen taustaan. Näin ollen esimerkiksi vääristä lähtökohdista rakennettu luonnontieteen tai fysiikan perustelu voi sisältää Toulminin analyysin näkökulmasta rakenteellisesti oikeat palaset, mutta olla silti fysiikan sisältötiedon kannalta ristiriitainen tai jopa väärin. Toulminin mallin tarkoituskin on toimia yleisenä argumentoinnin viitekehyksenä ja sen soveltaminen johonkin tiettyyn tieteenalaan vaatii lähes aina kriteerien tarkentamista joko episteemisestä (Sandoval \& Millwood, 2005; Nousiainen, 2017; Vuola \& Nousiainen, 2020) tai rakenteellisesta (ks. esim. Böttcher \& Meisert, 2011) näkökulmasta. Böttcherin ja Meisertin analyysimalli tarjoaa kiinnostavan mahdollisuuden kuvata hyvin tarkasti opiskelijoiden selitysmallien kehittymistä kohti tieteellistä selitysmallia. Työläydestään huolimatta se soveltuu tässä esitetyistä malleista parhaiten juuri fysiikan tiedon analysoimiseen, sillä se tunnistaa fysiikan tiedon empiirisen ja teoreettisen puolen yhtä tärkeinä. Mallien korostaminen fysiikan tiedon kuvailussa tukee myös fysiikan tietorakenteen kokonaisvaltaista ymmärtämistä (Mäntylä \& Nousiainen, 2014). Böttcherin ja Meisertin analyysimalli poikkeaa tässä artikkelissa esitetyistä muista analyysimalleista merkittävimmin siinä, että se on alun perin tarkoitettu luokkahuonekeskusteluna tai pienryhmätyöskentelykeskusteluna kerätyn aineiston analysointiin. Tämän vuoksi analyysimallien vertailu jonkin yksittäiseen esimerkkiin nojautuen ei ole mahdollista. Sampsonin malli on kattava erityisesti siksi, että siinä esitetään arviointikriteerit erilaisten argumenttien arvioimiseksi. Argumentin osatekijöiden rajaus on fysiikan näkökulmasta osin ongelmallinen, sillä mallissa evidenssi nähdään empiirisenä havaintoaineistona ja siitä tehtyinä tulkintoina, jolloin teoriatietoon nojautuvat ennusteet eivät mallin mukaan muodostaisi argumenttia. Sampsonin malli olisi hyödynnettävissä kattavammin fysiikan opetuksessa, jos evidenssiin sisällytettäisiin empirian lisäksi teoreettisia tietorakenteita, jolloin fysiikan sisältötiedon käytön ja esittämisen voisi jäsentää argumentin muotoon myös teoreettisissa ongelmanratkaisutehtävissä. Sandovalin ja Millwoodin malli erittelee argumentin käsitteellistä ja episteemistä laatua: onko sisältö tieteenalan näkökulmasta järkevä ja onko sen argumentointi uskottavaa. Malli paneutuu erityisesti kokeelliseen dataan nojautuvaan perusteluun ja jättää teoriataustan kokonaan 
huomiotta. Kuitenkin fysiikan tiedon kumulatiivisen luonteen takia ei ole aina välttämätöntä tai hyödyllistä perustella jokaista argumentissa käytettyä fysiikan lakia kokeellisesti ja toisaalta kokeellinenkin tutkimus perustuu aikaisempiin fysiikan lakeihin.

Argumentointimalleja tarkastelemalla voidaan luoda perustaa tieteenalakohtaisten tiedonmuodostusprosessien integroimiseksi osaksi formaalia opetustoimintaa ja oppimisen arviointiin fysiikan kontekstissa. Fysiikan sisältötiedon opetus ja erityisesti fysiikan opettajankoulutus voisi hyötyä argumentointitaitojen painotuksessa osana opetusta, mutta tähän kuitenkin tarvitaan argumentointimalli, jonka kriteerit kumpuavat nimenomaan fysiikan tiedon luonteesta huomioiden myös fysiikan opettamisen näkökulman. Tässä yhtenä kiinnostavana vaihtoehtona tällaisen mallin luomisessa voisi jatkossa olla Wolhrappin (2014) näkemys, jossa hän näkee argumentoinnin oleellisena osana opetusta ja opettajan taitoa. Tällöin argumentoinnin näkökulmana on opetustilanteessa tiedon huolellinen perusteleminen jo olemassa tietoon nojautuen. Tämä prosessi eroaa uuden tiedon argumentoinnista siinä mielessä, että koulutuksessa opiskeltava sisältötieto on jo olemassa (opettajalle) ja sen voi opiskella: tieto on siis uutta vain opiskelijoille. Oppimiseen ja opettamiseen voidaan kuitenkin saada mukaan argumentatiivisia piirteitä, sillä opettajan tehtävänä on tiedon rekonstruointi oppimisen kannalta sopivaan muotoon ja järjestykseen. Olennaista olisi tuoda esille se, että uuden tiedonmuodostus tapahtuu olemassa olevan teorian pohjalta. Wohlrappin (2014) teittisyys (engl. thetic) voidaan tulkita fysiikan tiedonmuodostuksen sääntöinä, joiden puitteissa olemassa oleva tiedon perusteella luodaan uutta tietoa. Tällaista ainespesifiä, opetuksessa käytettävää argumentaatiota voitaisiin Wohlrappia mukaillen kutsua didaktiseksi argumentoinniksi.

Tällainen näkökulma ei kuitenkaan saanut tukea tässä artikkelissa esitetyissä argumenttimalleista. Jatkossa olisikin kiinnostavaa suuntautua rakentamaan fysiikan didaktisen argumentoinnin mallia. Wolhrapp (2014) näkee argumentoinnin ensisijaisesti toimintana, jolla voimme arvioida väitteiden tai teesien oikeellisuutta ja pätevyyttä (ks. myös Shebab \& Nussbaum, 2014). Tämä tulee melko lähelle Böttcherin ja Meisertin (2011) näkemystä mallien roolista fysiikan tiedon rakentumisessa. Fysiikan didaktisessa argumentoinnissa voisi siten hyvin tukeutua Wohlrappin näkemykseen teittisistä rakenteista, jotka ovat teoriaan perustuvia päämäärähakuisia rakenteita. Tämä on hyvin linjassa sen ajatuksen kanssa, että Sampsonin mallin (Sampson \& Clark, 2009; Sampson ym., 2011; Sampson \& Blanchard, 2012; Sampson ym., 2013) empiirisen evidenssin rinnalle lisättäisiin teoreettisen evidenssin näkökulma. Näin pystyisimme kuvaamaan paremmin fysiikan tiedonmuodostumisen kokeellista ja mallintavaa prosessia. Sandovalin ajatukset (Sandoval, 2003; Sandoval \& Millwood, 2005; 2007) argumentoinnin episteemisen ulottuvuuden huomioimisesta on siten myös mahdollista yhdistää osaksi fysiikan tiedon argumentointia.

Didaktisen argumentoinnin malli voisi tuoda perustan fysiikan tiedon luonteen mukaiselle ilmaisulle ja esitystavalle. Muun muassa Ylioppilastutkintolautakunta (YTL) edellyttää fysiikan kokelailta täsmällistä käsitteiden käyttöä ja fysiikan tiedon luonteen mukaista kielellistä ilmaisua ja esitystapaa (YTL, 2018). YTL ei kuitenkaan määrittele, mitä 


\section{Ainedidaktiikka 5(1) (2021)}

tällainen ilmaisu täsmälleen ottaen tarkoittaa. Fysiikan didaktisen argumentoinnin malli voisi luoda perustan fysiikan luonteen mukaisen ilmaisun määrittämiselle ja sen huomioimiselle osaamisen arvioinnissa. Tällöin fysiikan osaaminen edellyttäisi nykyistä vahvemmin tieteenalalle ominaista argumentointia, mikä voisi suunnata opetuksen painopistettä muun muassa tietoteknisistä apuvälineistä kohti kriittisyyttä, ajattelun eheyttä sekä hyvin jäsenneltyjen oppisisältöjen hallintaa. Tällainen painopisteen muutos luonnollisesti vaikuttaisi myös aineenopettajakoulutukseen ja sen puitteissa käytettäviin työtapoihin, joilla pyritään takaamaan mahdollisimman hyvät lähtökohdat fysiikan opettajaksi kasvamisessa.

\section{Kiitokset}

Tätä tutkimusta on rahoittanut Suomen Akatemian hanke nro 311449.

\section{Lähteet}

von Aufschnaiter, C., Erduran, S., Osborne, J. \& Simon, S. (2007). Arguing to learn and learning to argue: Case studies of how students' argumentation relates to their scientific knowledge. Journal of Research in Science Teaching, 45(1), 101-131. https://doi.org/10.1002/tea.20213

Böttcher, F. \& Meisert, A. (2010). Argumentation in Science Education: A Model-based Framework. Science \& Education, 20, 103-140. https://doi.org/10.1007/s11191-010-9304-5

Cavagnetto, A. R. (2015). Argument to foster scientific literacy: A review of argument interventions in K-12 science contexts. Review of Educational Research, 80(3), 336-371. https://doi.org/10.3102/0034654310376953

Crouch, C. H. \& Mazur, E., (2001). Peer Instruction: Ten years of experience and results. American Journal of Physics, 69(9), 970-977. https://doi.org/10.1119/1.1374249

Erduran, S., Ozdem, Y. \& Park J-Y. (2015). Research trends on argumentation in science education: a journal content analysis from 1998-2014. International Journal of STEM Education, 2, 1-12. https://doi.org/10.1186/s40594-015-0020-1

Erduran, S., Simon, S. \& Osborne, J. (2004). TAPping into Argumentation: Developments in the application of Toulmin's Argument Pattern for studying science discourse. Science Education, 88(6), 915-933. https://doi.org/10.1002/sce.20012

Docktor, J. \& Mestre, J. (2014). Synthesis of discipline-based education research in physics. Physical Review Special Topics - Physics Education Research, 10(2), 1-58. https://doi.org/10.1103/PhysRevSTPER.10.020119

Driver, R., Newton, P. \& Osborne, J. (2000). Establishing the Norms of Scientific Argumentation in Classrooms. Science Education, 84(3), 287-312. https://doi.org/10.1002/(SICI)1098-237X(200005)84:3<287::AIDSCE1>3.0.CO;2-A

Fischer, F., Kollar, I., Ufer, S., Sodian, B., Hussmann, H., Pekrun, R., Eberle, J. (2014). Scientific reasoning and argumentation: Advancing an interdisciplinary research agenda in education. Frontline Learning Research, 2(3), 28-45. https://doi.org/10.14786/flr.v2i2.96

Jiminéz-Aleixandre, M. P. \& Erduran, S. (2008). Argumentation in science education. An overview. Teoksessa S. Erduran \& M. P. Jimenéz-Aleixandre (toim.), Argumentation in science education (s. 3-27). Dordrecht: Springer. https://doi.org/10.1007/978-1-4020-6670-2 1

Kelly, G. J., Regev, J. \& Prothero, W. (2008). Analysis of Lines of Reasoning in Written Argumentation. Teoksessa S. Erduran \& M. P. Jiménez-Aleixandre (toim.), Argumentation in Science Education: Perspectives in Classroom-Based Research (s. 137-158). Dordrecht: Springer. 


\section{Ainedidaktiikka 5(1) (2021)}

Kokkonen, T. \& Laherto, A. (2018). Tiedeopetuksen muuttuvat tavoitteet-sisältötiedosta luonnontieteelliseen lukutaitoon. Ainedidaktiikka, 2(1), 20-38. https://doi.org/10.23988/ad.69250

Koponen, I. T. \& Kokkonen, T. (2014). A systemic view of the learning and differentiation of scientific concepts: The case of electric current and voltage revisited. Frontline Learning Research, 2(3), 140-166. https://doi.org/10.14786/flr.v2i2.120

McDermott, L. (2001). Physics Education Research - The Key to Student Learning. American Journal of Physics, 69(11), 1127-1137. https://doi.org/10.1088/2058-7058/17/1/37

Meltzer, D. \& Thornton, R. K. (2012). Resource Letter ALIP-1: Active-Learning Instruction in Physics. American Journal of Physics, 80(6), 478-496. https://doi.org/10.1119/1.3678299

Mercer, N. (2009). Developing Argumentation: Lessons Learned in the Primary School. Teoksessa N. Muller Mirza \& AN. Perret-Clermont (toim.), Argumentation and Education (s. 177-194). Boston, MA: Springer. https://doi.org/10.1007/978-0-387-98125-3 7

Mäntylä, T. \& Nousiainen, M. (2014). Consolidating pre-service physics teachers' subject matter knowledge using didactical reconstructions. Science \& Education, 23(8), 1583-1604. https://doi.org/10.1007/s11191-013-9657-7

Newton, P., Driver, R. \& Osborne, J. (1999). The place of argumentation in the pedagogy of school science. International Journal of Science Education, 21(5), 553-576. https://doi.org/10.1080/095006999290570

Nousiainen, M. (2013). Coherence of Pre-service Physics Teachers' Views of the Relatedness of Physics Concepts. Science \& Education, 22, 505-525. https://doi.org/10.1007/s11191-012-9500-6

Nousiainen, M. (2017). Organization of physics content knowledge for teaching purposes: From knowledge justification schemes to didactical schemes. European Journal of Science and Mathematics Education, 5(2), 210-209. https://doi.org/10.30935/scimath/9507

Rapanta, C., Garcia-Mila, M. \& Gilabert, S. (2013). What is meant by argumentative competence? An integrative review of methods of analysis and assessment in education. Review of Educational Research, 83(4), 483-520. https://doi.org/10.3102/0034654313487606

Redish, E. F., Saul, J. M. \& Steinberg, R. N. (1998). Student expectations in introductory physics. American Journal of Physics, 66(3), 212-224. https://doi.org/10.1119/1.18847

Redish, E. F. \& Steinberg, R. N. (1999). Teaching Physics: Figuring out What Works. Physics Today, 52(1), 24-30. https://doi.org/10.1063/1.882568

Osborne, J. \& Patterson, A. (2011). Scientific argument and explanation: A necessary distinction? Science Education, 95(4), 627-638. https://doi.org/10.1002/sce.20438

Perkins, K. K., Adams, W. K., Pollock, S. J., Finkelstein N. D. \& Wieman, C. E. (2005). Correlating student beliefs with student learning using the Colorado Learning Attitudes about Science Survey. AIP Conference Proceedings 790, 61. https://doi.org/10.1063/1.2084701

Sampson, V. \& Clark, D. B. (2008). Assessment of the ways students generate arguments in science education: Current perspectives and recommendations for future directions. Science Education, 92(3), 447-472. https://doi.org/10.1002/sce.20276

Sampson, V. \& Clark, D. B. (2009). The Impact of collaboration on the outcomes of scientific argumentation. Science Education, 93(3), 448-484. https://doi.org/10.1002/sce.20306

Sampson, V., Grooms, J. \& Walker, J. (2011). Argument-Driven Inquiry as a Way to Help Students Learn How to Participate in Scientific Argumentation and Craft Written Arguments: An Exploratory Study. Science Education, 95(2), 217-257. $\underline{\text { https://doi.org/10.1002/sce.20421 }}$

Sampson, V. \& Blanchard, M. R. (2012). Science Teachers and Scientific Argumentation: Trends in Views and Practice. Journal of Research in Science Teaching, 49(9), 1122-1148. https://doi.org/10.1002/tea.21037 


\section{Ainedidaktiikka 5(1) (2021)}

Sampson V., Enderle, P., \& Grooms. J. (2013). Argumentation in science education Helping students understand the nature of scientific argumentation so they can meet the new science standards. The Science Teacher, 80(5), 30-33. https://www.jstor.org/stable/i40141452

Sandoval, W. A. (2003) Conceptual and Epistemic Aspects of Students' Scientific Explanations. The Journal of the Learning Sciences, 12(1), 5-51. https://doi.org/10.1207/S15327809JLS1201_2

Sandoval, W. A. \& Millwood, K. A. (2005). The Quality of Students' Use of Evidence in Written Scientific Explanations. Cognition and Instruction, 23(1), 23-55. https://doi.org/10.1207/s1532690xci2301 2

Sandoval, W. A., \& Millwood, K. A. (2007). What can argumentation tell us about epistemology? Teoksessa S. Erduran, \& M. P. Jiménez-Aleixandre (toim.), Argumentation in science education (s. 71-88). Dordrecht: Springer. https://doi.org/10.1007/978-1-4020-6670-2_4

Tiruneh, D.T., De Cock, M. \& Elen, J. (2018). Designing learning environments for critical thinking: Examining effective instructional approaches. International Journal of Science and Mathematics Education, 16(6), 1065-1089. https://doi.org/10.1007/s10763-017-9829-z

Toulmin, S. E. (2003). The Uses of Argument. Cambridge: Cambridge University Press. https://doi.org/10.1017/CBO9780511840005

Turiman, P., Omar, J., Daud, A. M. \& Osman, K. (2012). Fostering the 21 st century skills through scientific literacy and science process skills. Procedia - Social and Behavioral Sciences, 59, 110-116. https://doi.org/10.1016/j.sbspro.2012.09.253

Vuola, K. \& Nousiainen, M. (2020). Physics knowledge justification: an analysis framework to examine physics content knowledge. Nordic Studies in Science Education, 16(2), 149-166. https://doi.org/10.5617/nordina.6916

Wohlrapp, H. (2014). The Concept of Argument. Dordrecht: Springer. https://doi.org/10.1007/978-94-017-8762-8

Ylioppilastutkintolautakunta (2018). Tiedote fysiikan opettajille ja opiskelijoille. https://www.ylioppilastutkinto.fi/images/sivuston tiedostot/Sahkoinen tutkinto/fy tiedote fi-1.pdf (haettu 16.3.2021) 